\title{
Noise Level Measuring Options and Their Use in Technological Processes
}

\author{
Kristiāns Štekelis \\ Latvia University of Agriculture, kristians.stekelis@rtk.lv
}

\begin{abstract}
Working environment has changed in the last few years and work has become more intensive i.e. demand for maximum attention and concentration, workload adaptions with the mental and physical abilities of human, solvation of various organising issues. Risk factors of working environment can be found in every profession and may affect a large number of employees. One of the essential issues in wood processing is noise presence during machining, which is why noise level determination at the workbench during whole working day is important thing to do.

Measuring devices of the noise level are with various technological abilities, from which one need to choose the most appropriate for the particular situation. Some of the devices are or may be equipped with data recorder, which allows to save measured data for subsequent computer assessment. The article analyses Latvian legislation concerning the noise level determination in the workplace as well as allowable limits. The article offers simplified means of the noise measurement and registration abilities.
\end{abstract}

Keywords - noise recorders, noise measurements.

\section{INTRODUCTION}

Employees of various professions and from various fields in the whole world each day are succumbed to vital work environment risks. The work environment risk is possibility that the security or health of the employee may be damaged during the working process as well as the severity of the possible damage [1]. The working process risk includes draught, noise, vibration, dangerous substances etc. factors. In the wood processing especially expressed is noise presence during the machining. Noise as the working environment risk is essentially dangerous since it is not painful during the injury. It has lasting effect, which may be irreversible, which is why it is important to realize all the bad impact on the health of the employees as well as allowable noise exposure time according to noise exposure level.

The allowable noise level at the workplace is determined by the Cabinet Regulation No 66 "Labour Protection Requirements for employee protection against the noise risk at the workplace" [1] which mentions:

- The measurement and assessment of the noise risk;

- The assessment and reducing of the noise level;

- The use of personal protective equipment

- Health check of the employees

- The procedure of the noise measurement

- The allowable noise exposure time according to noise exposure level, which exceeds the threshold of the exposure level $\mathrm{L}_{\mathrm{ex}} 8_{\mathrm{h}}=87 \mathrm{~dB}(\mathrm{~A})$.

The measurement and determination of the noise has been regulated by the Latvian State standards, where information can be found about:

- Calculation methods for the noise-induced hearing threshold of the expected permanent displacement, divided in threshold levels for adult target group that appeared during various noise level exposures LVS ISO 1999:2007 [2];

- Calculation of the noise level and exposure at the workplace, where noise has been determined by A and C levels, which means the usage or switching off the frequency filter. LVS EN ISO 9612:2009 [3];

- Testing methods of the basic noise emission to determine noise at the various wood processing working machines LVS ISO 7960:2005 [4];

- Determination of the noise emission pressure at the working machines at workplace or other specific places by using sound intensity. LVS EN ISO 11205:2010 [5].

Based on the State Labour Inspectorate's first semiannual report about approved occupational diseases that are connected with hearing, during 2011 has been detected 16 cases, but during 2012 first semi-final 11 cases [6].

Employer has to control the noise level at the workplace. It has to be done by verified equipment and it must create the working environment according to Ministry Regulation No 66 conditions [1]. To attract employers for purchase of the noise level measurement and registration devices, the article compares various noise level registrars and their capabilities. That means that employer personally may control the situation in processing plant and if necessary make all the working environment improvements.

\section{MATERIALS AND METHODS}

\section{Theoretical justification of noise}

Noise is a risk factor of the working environment, which creates discomfort for employees. If human is continuously exposed to such noise effect that exceeds 80 $\mathrm{dB}(\mathrm{A})$ there is a chance that with time his/her hearing will worsen and hearing injury will appear. 
Severity of the injury depends on noise level and exposure time, as well as sensitivity level of each person individually. Hearing injury is inner ear nerve cell damage. Hearing injury cannot be treated and usually it causes social isolation. Noise may cause not only hearing injury, but also stress, high blood pressure, fatigue, insomnia etc. It may stimulate exacerbation of other diseases and related absenteeism, accidents and increased number of errors [7]. A large number of employees who are employed in wood processing plants and furniture manufactories are exposed to such noise level that even hardens the communication of the workers. In lot of workplaces noise level exceeds $90 \mathrm{~dB}(\mathrm{~A})$ and in some places even more.

The biggest noise level creates the mechanical processing of wood. They are fast moving and rotary cutting tools, which are shifting from one level into another, parts that are interfering with each other, pressured air from the pneumatic systems and noise from the ventilation system. Impulsive noise is also typical for this field when pressured air is discharging from various pneumatic tools or when massive objects are smashing together [7].

Two main characteristics of the noise are frequency that is measured in hertz $(\mathrm{Hz})$ and intensity that is measured in decibels $(\mathrm{dB}(\mathrm{A}))$. Person's organ of hearing perceives sound vibrations of $16 \ldots 20000 \mathrm{~Hz}$. Practical significance for sound is frequency zone, that corresponds to manufacturing conditions $(40 \ldots 10000 \mathrm{~Hz})$ because it includes the most of the manufacturing noises [4]. A wide range of frequency zones determines Equivalent noise pressure level by using $\mathrm{dB}(\mathrm{A})$ measurements. According to Europe standards (ISO 1996/1) there is a specific terminology for determination of this measurement: A weighted sound pressure level $\left(\mathrm{L}_{\mathrm{pA}}\right)$ [8].

The noise may be theoretically divided into three groups: low-frequency noise, when frequency is lower than $300 \mathrm{~Hz}$, average-frequency $-300 \ldots 1000 \mathrm{~Hz}$ and high-frequency when frequency is higher than $1000 \mathrm{~Hz}$. The intensity of sound or volume has been determined in decibels $(\mathrm{dB})$ that is logarithmic sound. Fact that the noise is dangerous can be determined by four factors: the intensity of sound or volume, frequency or tune, periodicity (how often in sounds) and duration (how long it sounds).

Level of the noise cannot exceed the noise exposure limit $(87 \mathrm{~dB}(\mathrm{~A}))$ or at the working place higher than $(140$ $\mathrm{dB}(\mathrm{A}))$ depending on the Ministry Regulation No 66. If the threshold of the noise exposure has been exceeded, all the necessary occupational health and safety measures must be done immediately and noise level must be reduced at least to its exposure threshold $(87 \mathrm{~dB}(\mathrm{~A}))$ [1].

\section{Methodology of noise determination}

The methodology of noise determination has been determined on $4^{\text {th }}$ of February 2003 by Ministry Regulation No 66, 1 appendix [1]. Noise measurements are being done to determine the environmental noise level, as well as for noise effect determination on person and his/her hearing. During the noise determination, following conditions must be met.

- manufacturer's technical documentation for noise measurement equipment, where information about noise level determination can be found. Even though noise level determination process is similar, various companies have various models therefore technological capabilities of the device are different;

- all the regulations of occupational health and safety that concerns the specific environment where noise level measurements will be done, must be observed;

- before the working day ensure, that calibration term for equipment, which will be used, has not expired, otherwise biased measurement results may appear;

Before the beginning of noise level measurements the following measures must be done;

- observe the intended measurement's place, if it will be in facility or outside, check all the organizing issues, for example, measurement time, accessibility of the object and other operations necessary for measurement's preparation;

- check the microphone, accumulator and condition of device and make all the necessary measurement preferences;

During the noise level measurements, following conditions must be met;

- before and after each measurement, equipment preferences must be set and acoustic test of the microphone must be done;

- duration of the measurements is long enough to make all the necessary noise measurements and acquire sufficient amount of data;

- intermittent noise measurement time interval contains at least one full working cycle, characterised to noise source, but no less than 20 minutes;

- measurement duration, place and type is determined based on corresponding standard recommendations. During measurements, environmental conditions (side noise and direction of wind) and noise characteristical changes must be taken into consideration;

By choosing noise level measurement points, following conditions must be met:

- measurement points are determined based on applied measurement methodology recommendations to avoid measurement errors from other devices;

- in the place and territory of measurements at least three measurement points must be done;

When choosing measurement points, microphone should be placed at least $3,5 \mathrm{~m}$ from any reflective surface except for the earth's surface. Microphone must be placed $1,2 \mathrm{~m}-1,5 \mathrm{~m}$ above the earth.

If presence of employee is necessary or measurements are taken while employee is moving around, microphone must be placed $0,10 \mathrm{~m}-0,01 \mathrm{~m}$ from employees ear, that receives most of the $\mathrm{dB}(\mathrm{A})$ - weighted sound exposure or equivalent uninterrupted $\mathrm{dB}(\mathrm{A})$ - weighted sound pressure level.

When choosing measuring points in facility, they must be at least $1 \mathrm{~m}$ from the wall or other huge reflective surfaces e.g. 1,5 m large window and 1,2 $\mathrm{m}-1,5 \mathrm{~m}$ above 
the floor. If the specific workplace does not have any specific indications, then the amount of measuring points (n) must be chosen by the following formula:

$$
n=4 \cdot \lg \left(\frac{V}{50}+2\right)+2 \text {, }
$$

where $\mathrm{n}$ - the amount of measurement points, rounded to the nearest integer;

$$
\mathrm{V} \text { - volume of room, } \mathrm{m}^{3}
$$

Measuring points near the noise source usually don't place in the area, that is twice as big as its largest body.

In addition to aforementioned conditions, following demands must be complied:

- in accordance to aforementioned conditions microphone placement, measurement values, test bandwidth, measurement duration and other characteristic conditions;

- write down all the noise sources that is sounding during the measurement, their location, measurement equipment position, direction of microphone and distance till the noise source. Background noises are measured at the same measurement points as the investigation's noise point;

- if undesirable side noises appears (noncharacterised to investigating noise), measurements must be stopped as well if conditions for the measurements haven`t been met or measurement place selection`s underlying principles haven`t been complied.

Noise from machines and devices determines as timeweighted equivalent noise level $L_{A e q T}, \mathrm{~dB}(\mathrm{~A})$. Letter $\mathrm{A}$ behind $\mathrm{dB}$ indicates that measurement equipment is set for measuring in the scale A (all audible from $20 \mathrm{~Hz}$ to $20 \mathrm{kHz})$.

The noise effect on person determines by allowable noise exposure's performance value i.e. daily noise exposure level in the working environment during shift, $\mathrm{L}_{\mathrm{EX} \text {,mainā, }} \mathrm{dB}(\mathrm{A})$.

There are as follows noise exposure thresholds and exposure`s performance values:

- threshold of noise exposure: $\mathrm{L}_{\mathrm{EX} \text {,maiñā }}=87 \mathrm{~dB}(\mathrm{~A})$ and maximum threshold level during short-term performance $\mathrm{L}_{\max }=140 \mathrm{~dB}(\mathrm{~A})$;

- the highest allowable noise exposure value, particularly in case when Personal hearing protection is not accessible: $\mathrm{L}_{\mathrm{EX} \text {,maināa }}=85 \mathrm{~dB}(\mathrm{~A})$ ) and maximum threshold level during short-term performance $\mathrm{L}_{\max }=135$ $\mathrm{dB}(\mathrm{A})$.

During noise level measurements at workplace, the Personal hearing protection impact is not taken into the consideration. Eveready's noise exposure level $\mathrm{L}_{\mathrm{EX} \text {,maiñā }}$ determines by time, that employee needs to spend in noisy environment and by using mathematical calculations or computer software - calculator. If, during a working week in the specific workplace, the noise level significantly differs during day-time hours, employer is entitled to change noise level determination from every day's noise exposure level to average weekly noise exposure level [9].

\section{Noise measuring devices}

For qualitative noise level determination a several measuring devices are necessary. Primarily, it is a noise level determination device. Sometimes these devices are equipped with display, where noise level can be seen during the measurements. Usually these devices work on batteries or accumulator and are not quite big, which means that they are easily movable. With such devices, measurements at workplace can be done comfortably but if data analysis is necessary, then additional noise pressure level reader and storage module are required. It may be built in measuring device or separately connected to noise registration device, if it has necessary output. The main task of the device is recording the level of noise changes. It is necessary to store data and analyse them later on the computer. Changes in the level of noise must be recorded with interval, which sometimes changes and gives a lot of data, which can be later analysed. With hand-writing such data cannot be written as fast. To set up and run noise pressure level reader and storage module, a computer with software that comes together with device is required.

A various devices may be used for noise recording: integral or broad frequency range sound level measuring devices $(\mathrm{dB}(\mathrm{A})$ scale) octave zone (individually separate frequencies) sound analysers, individual noise dosimeters, sound impact level indicators, devices for calibration of aforementioned equipment etc. There are also electronic measuring devices (multi-dosimeters) that combine several measuring functions.

A lot of companies are offering for purchasing sound level measuring devices, with the price range that is quite huge, ranging from a few tens of dollars (e.g. Triplett TSC-MC1 [10]) to several hundreds of dollars for one measuring device (e.g. SDL600 [11]) or even several thousands of dollars for one measuring system. The price of the device basically depends on its application possibilities:

- either its calibrated or not;

- either it can be connected to computer;

- either it has memory card;

- either it has a switchable range option;

- precision of measurements and acquired data amount per second;

- software for data processing etc.

Cheaper devices usually are for approximate noise level measurement at the specific moment, without an option for recording and analysing data later. Average priced devices can be connected to computer, which also allows to connect data storage device that makes it an intermediary between device and computer, for storage of a recorded data, e.g. HOBO U12 [12]. Data storage device can be connected to several other devices and save data, which can be later analysed on computer. In that way a cheaper device may be bought, without unnecessary purchase of memory cards and built in data storage devices. Measuring device, of course, must have output to connect it with data storage device. Expensive measuring devices have built-in data storage, which allows reading of registered data, when device is 
connected to computer. There are devices which save information on memory cards, which allow to copy data on computer. Particular software should also be taken into consideration, which allows process and send data, for example, to MS Excel software for graph, curve or other figure modelling. Expensive measuring devices may be connected to network, which allows to make a measuring system and look on noise level data at the making moment in the particular workplace e.g. NTi Audio XL2 [13]. Several measuring devices from each price category may be seen in table 1, which also shows comparison of characteristic parameters.

TABLE 1.

NOISE RECORDERS

\begin{tabular}{|c|c|c|c|c|c|}
\hline Model & 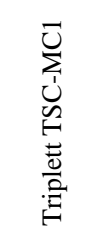 & 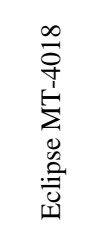 & 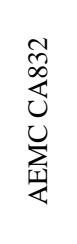 & 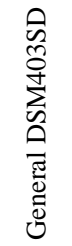 & 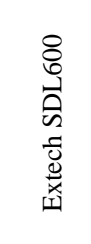 \\
\hline Range, dB & $40-130$ & $30-120$ & $\begin{array}{l}30- \\
130\end{array}$ & $\begin{array}{l}30- \\
130\end{array}$ & $30-130$ \\
\hline $\begin{array}{l}\text { Basic accuracy, } \\
\text { dB }\end{array}$ & - & \pm 3.0 & \pm 1.5 & \pm 2.0 & \pm 1.4 \\
\hline Weighting & - & - & $\begin{array}{l}\text { A } \\
\text { and } \\
\text { C }\end{array}$ & $\begin{array}{l}\text { A } \\
\text { and } \\
\text { C }\end{array}$ & $\begin{array}{l}\text { A and } \\
\mathrm{C}\end{array}$ \\
\hline $\begin{array}{l}\text { Response } \\
\text { Time, sec. }\end{array}$ & - & 0.750 & 0.5 & 1.0 & 0.125 \\
\hline Datalogging & - & - & - & $\begin{array}{l}\text { SD } \\
\text { card }\end{array}$ & $\begin{array}{l}\mathrm{SD} \\
\text { card }\end{array}$ \\
\hline Analog Output & - & - & $\mathrm{AC}$ & - & $\mathrm{AC}$ \\
\hline PC Interface & - & - & - & - & USB \\
\hline $\begin{array}{l}\text { Price (for } \\
01.02 .2013 . \text { ) }\end{array}$ & $\$ 30.95$ & $\$ 89.95$ & $\$ 199$ & $\$ 355$ & $\$ 780$ \\
\hline
\end{tabular}

Table shows, that analogue output, that allows to connect data recorders, is available only at the average price range e.g. HOBO. With simpler devices it is possible to determine specific noise level at the particular measurement place, without a chance to save these data. A possible error chance also increases and on simplified devices such parameter is not shown at all. Table also shows, that technologically better devices may save several data in one second, but it should be noted, that data recording frequency effects memory, because the more data the more memory`s capacity is necessary. Some devices allow weighting frequency filter A or C. As table 1 shows, direct computer connection is available only for technologically better devices, which are equipped with USB connection. It also shows that such devices are very expensive and propose to choose cheaper devices that can be connected with computer.

Offer for noise level measurement devices is wide, so considering that particular situation is known, it is possible to choose the most efficient option for noise level measurement, recording or monitoring.

\section{Example of the noise measurement.}

For noise level measurements a noise level recording device "Sound level meter 93411" have been used, which provides short-term acoustic pressure level measurements and noise pressure reading and storing module "Hobo H08-004-02", which allows to send acquired data to computer, where they can be easily processed (pic. 1)

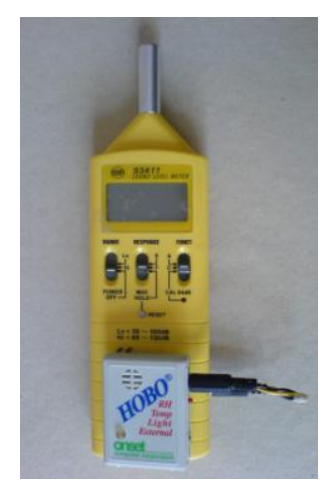

Pic. 1 Sound level meter and Hobo

Data recording must be according to work methodology, which provides information about data recorder's placement, data recording time, period and beginning and finish of the recording. At the beginning of work, module must be connected to computer's Com port. Specifically with Hobo software the necessary settings must be set. For example, about delayed start beginning time, record interval of the necessary data etc. When all the needed corrections have been made, module must be activated and record may begin

When data record has been finished, module must be connected to computer once again, to load information from module to computer's software file. Loaded data on the computer appears in the form of table, which may be consulted, copied, printed and sent to different software e.g. MS Excel and process necessary parts of data.

\section{RESULTS AND DISCUSSION}

Measured data may be stored in the workplace and offers results digitally, that allows us to save, forward and analyse them by using various software. For example, a diagram may be extracted, that shows noise level during the process (Pic. 2). 


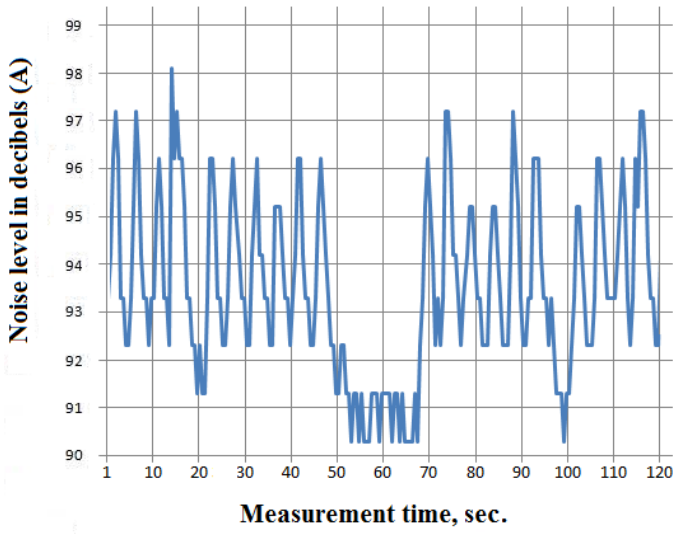

Pic. 2 Noise level at the workplace during wood processing

The given example shows noise level of the circular saw machine during wood processing, which is recorded in two minutes long interval. As it shows, this workplace mostly have $92,3 \mathrm{~dB}(\mathrm{~A})$ to $96,2 \mathrm{~dB}(\mathrm{~A})$ noise level. A peak noise of $98,1 \mathrm{~dB}(\mathrm{~A})$ can also be seen, which is short and is not characteristic compering to all processing time. Graph also shows that in period between 50 to 70 seconds the level of noise significantly lower, which means that during this stretch work stopped and machine worked at idle. As seen in example, such noise level analysis gives insight about noise level at the workplace as well as its dynamics. It means that employer may control this noise level from an occupational health perspective and decide if additional improvements at company are really necessary, so that it would correspond to Ministry Regulation No 66 conditions [1]. The noise level data may be also used to keep an eye on other processes, like working machine's workload. If continuous data recording has been made then later it may be evaluated in the form of diagram, sum up time, during which the working machine has worked at idle and how long at downtime. Such information would help to optimize processing work time. Noise level data gives an opportunity to control and manage technological processes.

To make possible control and management of the surface quality by applying noise level record, it is important to measure noise during inter-sharpening time of the cutting tool. It means that noise level measurements should be done right after change of new cutting tool and until the moment, when surface quality is not satisfactory. Noise level can be measured on an on-going base or cyclically. If during the processing time noise raises a bit, the main reason is worn off cutting toll which lead to worse surface quality. So under certain processing conditions it is possible to make provisions about surface quality according to noise level data. When the processing conditions are changing (e.g. type of wood, cutting depth or material supply rate) the level of noise will change but noise level increase connection during the processing will remain. Publication may serve as a basis to choose appropriate noise level recording device for noise level data acquisition.

\section{CONCLUSION}

Companies are offering various noise level recorders with many different functions and possibilities.

Not every noise level recorder can save data for later analysis.

Noise level measurements play an important role in technical, technological, economical and social processes of wood manufacturing.

Noise level measurements at workplace give an opportunity to follow and assess changes in the working environment to take all the necessary actions to improve this environment and protect employees from undesirable noise effect.

Causes between noise level and quality of workpiece correlates, which may be affected by worn off cutting tool, work machine`s technical condition and other important issues related to manufacturing.

By improving (digitizing) the noise level's measurement methodology, it would make possible to follow up not only the surface quality of the processing material and make judgements about the cutting toll`s worn off condition, but also develop the volume of cutting toll`s exchange cycle, track finished work and working machine`s workload, technical service maintenance and repair.

\section{REFERENCES}

[1] Darba aizsardzības prasības nodarbināto aizsardzībai pret darba vides trokšña radīto risku: Ministru kabineta noteikumi Nr.66, (pieņemti 2003. gada 4.februārī);

[2] “Akustika. Darba vides trokšna ekspozīcijas noteikšana un trokšna izraisītu dzirdes bojājumu prognozēšana“ LVS ISO 1999:2007;

[3] "Akustika. Darba vides trokšņa ekspozīijas noteikšana. Tehniskā metode (ISO 9612:2009)" LVS EN ISO 9612:2009;

[4] „Darbgaldu emitētais gaisa nestais troksnis - Kokapstrādes darbgaldu ekspluatācijas nosacījumi” LVS ISO 7960:2005;

[5] „Akustika. Mašīnu un iekārtu emitētais troksnis. Inženiermetode, kā ar skaņas stipruma metodi noteikt emitētās skaņas spiediena līmenuus mašīnas/iekārtas darbvietā vai citā norādītā vietā (ISO 11205:2003)" LVS EN ISO 11205:2010;

[6] Valsts darba inspekcijas 2012. gada 1 pusgada pārskats [skatīts2013.g.febr.].Pieejams: http://www.vdi.gov.lv/files/parskats_2012_1pusgads.pdf;

[7] Kokapstrāde un mēbel̦u ražošana./ Darba aizsardzība: Rīga. Latvijas - Spānijas projekts, 2003. 30. lpp.;

[8] Kal̦ķis., V., Roja, Ž. Darba vides riska faktori un strādājošo veselības aizsardzība: Rīga. Elpa, 2001. 500. lpp.;

[9] Kalı̧ıis, V., Roja, Ž., Kaḷķis, H. Riski darba vidē: Rīga. 2007. 68.1pp;

[10] Trokšņa līmeņa mērītājs - Triplett TSC-MC1. Pieejams: http://www.testequipmentdepot.com/triplett/sound-level-meter/tscmc1.htm;

[11] Trokšņa līmeņa mērītājs - Extech SDL600. Pieejams: http://www.testequipmentdepot.com/extech/soundmeters/sdl600.ht $\mathrm{m}$;

[12] Datu uzkrājējs - HOBO U12. Pieejams: http://www.microdaq.com/occ/u12/u12-012.php;

[13] Trokšņa līmeņa mērītājs - NTi Audio XL2. Pieejams: http://www.akustiktest.de/NTI-XL2-Labview-PCFernsteuerung+Dauermess-Station+Pegelueberwachung.shtml 